Portland State University

PDXScholar

$5-15-1996$

\title{
Jacob and Wilhelm Grimm's Fairy Tales and Children
}

Cornelia Marianne Seigneur

Portland State University

Follow this and additional works at: https://pdxscholar.library.pdx.edu/open_access_etds

Part of the German Language and Literature Commons Let us know how access to this document benefits you.

\section{Recommended Citation}

Seigneur, Cornelia Marianne, "Jacob and Wilhelm Grimm's Fairy Tales and Children" (1996). Dissertations and Theses. Paper 5299.

https://doi.org/10.15760/etd.7171

This Thesis is brought to you for free and open access. It has been accepted for inclusion in Dissertations and Theses by an authorized administrator of PDXScholar. Please contact us if we can make this document more accessible: pdxscholar@pdx.edu. 


\section{THESIS APPROVAL}

The abstract and the thesis of Cornelia Marianne Seigneur for the Master of Arts in German were presented May 15, 1996, and accepted by the thesis committee and the department.

COMMITTEE APPROVALS:

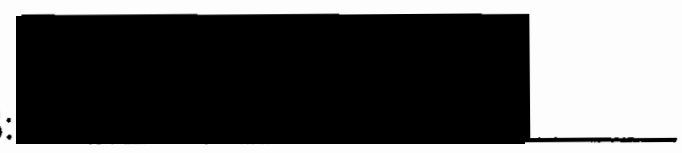

Louis Elteto, Chair

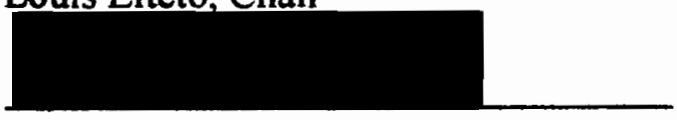

Steven Fuller

DEPARTMENT APPROVAL:

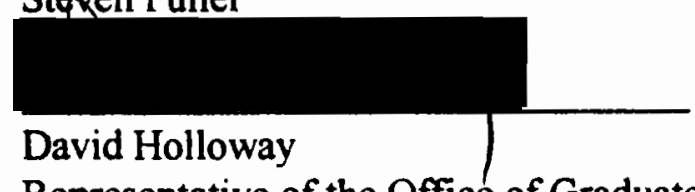

Representative of the Office of Graduate Studies

Louis Elteto, Chair

Department of Foreign Languages

ACCEPTED FOR PORTLAND STATE UNIVERSITY BY THE LIBRARY

by on

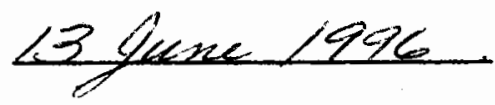




\section{ABSTRACT}

An Abstract of the thesis of Cornelia Marianne Seigneur for the Master of Arts in German, presented May 15, 1996.

Title: Jacob and Wilhelm Grimm's Fairy Tales and Children

Jacob and Wilhelm Grimm prided themselves on the notion that their collection of fairy tales, the Kinder-und Hausmärchen, was poetry from the Volk. Through their collection they sought to preserve the culture of a Germany disnupted by Napoleon.

Nlthough the Grimm brothers did not originally set out to write children's literature, it became a natural progression for their fairy tales to be used for children.

The Grimms were certain that their fairy tales should be read to children. They saw the naturainess in their tales, thereby claiming that the Kinder-und Hausmärchen would be a good "Erziehungsbuch." As people began to analyze fairy tales in relation to children, several reasons for their importance stand out: they present a child-like world view; they are naturally liked by children; they encourage the imagination; and they present a world of justice, with evil being punished and good rewarded.

A central criticism of Grimm fairy tales since the original publication in 1812 has been violence that they contain. Often times the evident gruesomeness is in the form of punishment of the villain. True to the nature of the Grimm brothers, some scholars feel 
that the essence of fairy tales embodies extremes, such as harsh punishments and wonderful rewards.

Differing perspectives have developed on how one should view fairy tales in relation to children. The first view is that one should take them as they are, unaltered, as the Grimms naturally recorded them; the second perspective is that one should not read them at all because of their extremes and gruesomeness; the third standpoint expresses caution, suggesting age-appropriate selections; and the fourth group sees the need to alter them into different renditions, as in the films of Walt Disney.

Because the Grimm brothers set the standard for the genre of the fairy tale, one should give children Grimms' Märchen unaltered. The Grimm brothers felt their fairy tales came directly from the Volk and that the natural lessons that grow out of them make them appropriate for both child and adult. 
JACOB AND WILHELM GRIMM'S FAIRY TALES AND CHILDREN

by

CORNELIA MARIANNE SEIGNEUR

A Thesis submitted in partial fulfillment of the requirements for the degree of

MASTER OF ARTS

in

GERMAN

PORTLAND STATE UNIVERSITY

1996 


\section{TABLE OF CONTENTS}

\section{ABSTRACT}

ACKNOWLEDGMENTS

CHAPTER

PAGE

INTRODUCTION: LIFE MYTI IS

I. THE BACKGROUND OF THE GRIMM BROTHERS

REASONS IFOR THEIR IMPOIRTANCE:

FOUR VIEWS

III. CONCLUSION:

GRIMM BROTIHEIRS SET THE STANDARD

WORKS CITED 


\section{ACKNOWLEDGMENTS}

I would like to thank my adviser Dr. Louis Elteto for his support in completing this project. Also thanks go to Dr. Steven Fuller for his enthusiasm and hard work as director of the Deutsche Sommerschule am Pazifik, where I was able to complete my Masters program.

Special thanks to my second cousin Helga Heni for mailing me many Grimm resources from Germany. Her encouragement in completing this project was very meaningful. And a heartfelt "Danke" to my parents, Margit and Helmut Becker, for raising me to speak German in the home. Growing up bilingual is a lifelong gift.

I extend a warm thank you for the unconditional love and acceptance from my mother-and-father-in-law, Nancy and David Seigneur. I feel blessed for their emotional support and help with my children while I attended classes and researched.

Further thanks go to my many wonderful friends and family who have been supportive of me during these years of study. Many helped with my children while I was in class or writing. I feel honored to have such caring people in my life.

Finally, to my husband Christopher, who shared this dream with me, I bestow seven years of thanks. "Herzlichen Dank" to you and our darling children Rachel and Ryan for your understanding and patience during the course of this program. Märchenstraße here we come!

Comelia Marianne Seigneur West Linn, Oregon May 1996 


\section{INTRODUCTION: LIFE MYTHS}

"In den alten Zeiten, wo das Wünschen noch geholfen hat . . . ."

"In the olden days when the art of wishing was still alive . . ." is my translation of the beginning of the first story ("Der Frosch König") in the collection of fairy tales attributed to Jacob and Wilhclm Grimm, titled Kinder-und Ilausmärchen (KHM). The phrase can be considered that which sums up the heart of fairy tales as they relate especially to children, that is, wishing for the impossible. Many critics consider fairy tales to be an integral part of childhood. The classic poet Friedrich Schiller reflected on the importance of fairy tales:

Tiefere Bedeutung liegt in dem Märchen meiner Kinderjahre als in der Wahrheit, dic das Leben lehrt. Dic heitre Welt der Wunder ist's allein, die dem entzückten Herzen Antwort gibt, die ihre ew'gen Räume mir eröffnct, mir tausend Zweige reich entgegenstreckt, Worauf der trunkne Geist sich selig wicgt. Die Fabel ist der Liebe Heimatwelt. (93)

Authors and illustrators of modern children's books share similar feelings. Jane Yolen, who writes various types of literature for children, including mythology, recalls childhood memories of fairy tales. Some Grimm fairy tales, she realized later, were "life myths" to her (Haase 284). P.L. Travers, who is the author of the children's book Mary Poppins, agrees that fairy tales teach about life. She calls fairy tales "old trees" that are: 
Rooted in the folk, full of meaning and ritual; they retell myths in terms that can be understood by unlettered people. For originally they were for the listener rather than the reader; they came long before books. Every one of these tales, it seems to me, is asking something of us, telling us something about life. (198)

Trina Schart Hyman, who has illustrated "Little Red Riding Hood" and "Snow White," recalls her German parents feeding her a diet of Grimms' fairy tales and Struwelpeter (Heinnich Hoffmann) at bedtime. "For me they were more than just bedtime stories--they were the Word, the Light, a whole way of approaching most things in life" (293). Although these authors and illustrators come from different eras, they share similar feelings as to the meaning of fairy tales in their lives, using word pictures such as "life myths," "old trees . . f full of meaning . . telling something about life," and "the Word, the Light." It is evident that the influence of fairy tales, which begins with the reading of them to children, continues into adulthood.

Familiarity with the term "fairy tale" brings recognition of the names Jacob and Wilhelm Grimm, commonly known as the Grimm brothers. Nlthough there were other collectors in the nineteenth century, it is the Grimm brothers who have left their mark on the history of the genre. They saw fairy tales in the same light that others did, believing that they teach about life. In the Vorrede of the first edition of their collection, the Kinder-und IJausmärchen of 1812 , 
Wilhelm Grimm describes how fairy tales affect people and how they inherently relate lessons about living:

In diesen Eigenschaften aber ist es gegründet, wenn sich so leicht aus diesen Märchen eine gute Lehre, eine Anwendung für die Gegenwart ergibt; es war weder ihr Zweck, noch sind sie darum erfunden, aber es erwächst daraus, wie eine gute Frucht aus einer gesunden Blüte ohne Zutun der Menschen. Darin bewährt sich jede echte Poesie, daß sie niemals ohne Beziehung auf das Leben sein kann, denn sie ist aus ihm aufgestiegen und kehrt zu ihm zurück. (qtd. in Schmitt 138)

The Grimm brothers prided themselves with the notion that their fairy tales were not necessarily intended to give a lesson about life, but that one grows out of them, like a "good fruit."

Although they began their university studies in law in $1802 / 03$ at the University of Marburg, their interest in languages and the cultural-poetical heritage of the German people inspired them intellectually. In their lifetime, they were responsible for compiling and writing a variety of philological works, such as Deutsche Sagen, Deutsche Mythologie, and Deutsches Wörterbuch. Still, they are probably best-known for their Kinder-und Hausmärchen (KIIM), their famous fairy tale collection, first published in 1812 .

With the inspiration of Achim von Amim and Clemens 
Brentano, the Grimm brothers began collecting stories in 1806 when Wilheim was 20 and Jacob 21 . Maria Tatar notes that, during Jacob's search for a publisher, his purpose was "to salvage what was left of the priceless national resources still in the hands of German folk" (Hard Facts 1 1). Although the Grimms wanted to preserve German culture through the collection of the tales, they did not call their collection "German"--instead, simply Kinder-und Hausmärchen-while their legends they titled Deutsche Sagen. The difference between the fairy tale and the legend genres may account for the reason: the fairy tale speaks a universal language, while the legend is specific to a certain locale. The Grimms summarize the difference between the two genres in the Vorrede of the Deutsche Sagen:

Das Märchen ist poetischer, die Sage historischer; jenes stehet beinahe nur in sich selber fest, in seiner angeborenen Blüte und Vollendung; die Sage, von einer geringern Mannigfaltigkeit der Farbe, hat noch das Besondere, daß sie an etwas Bekanntem und Bewußtem hafte, an einem Ort oder einem durch die Geschichte gesicherten Namen. Aus dieser ihrer Gebundenheit folgt, daß sie nicht, gleich dem Märchen, überall zu Hause sein könne. (7) What was the purpose of Märchen? As mentioned in the above quotations by various authors, fairy tales were thought to teach about life .- they give examples of how kindness and loyalty 
are rewarded and evil is punished. Compared to the tales of the French fairy tale collector Charles Perrault (1628-1703), in which the story has a lesson spelled out in the end. Grimms' fairy tales have a moral grow out of their tales. The Grimm brothers, as quoted above in the Vorrede of their 1812 KHM. "eine gute Lehre . . erwächst daraus, wie eine gute Frucht aus einer gesunden Blüte ohne Zutun der Menschen" (qtd. in Schmitt 139). The idea of the tales teaching people about life naturally led to using them for those whom society deems most teachable, namely the children. This brings into play the pedagogical value of the tales; noting how the Grimms titled their collection shows the realization that it could be used for children. As stated in the Vorrede of the Grimms' Deutsche Sagen:

Die Märchen also sind teils durch ihre aüßere Verbreitung, teils ihr inneres Wesen dazu bestimmt, den reinen Gedanken einer kindlichen Weltbetrachtung $\mathrm{zu}$ fassen, sie nähren unmittelbar, wie die Milch, mild und lieblich, oder der Honig, süß und sättigend, ohne irdische schwere. (8)

The "kindliche Weltbetrachtung" that the Grimm brothers mention is the view point of the fairy tale, a child-like view point. Goethe so eloquently stated his feeling about the beauty of fairy tales:

Märchen: das uns unmögliche Begebenheiten unter möglichen oder unmöglichen Bedingungen als möglich darstellt. (498) 
This statement by Goethe summarizes the ambiguity between the wishful world of the fairy tale and the reality of everyday life. The child-like world view within a fairy tale overlooks the conflict and believes that wishing for the impossible still helps: "wo das Wünschen noch geholfen hat." 


\section{CHAPTER 1}

\section{THE BACKGROUND OF THE GRIMM BROTHERS AND THEIR MÄRCHEN STYLE: NATURPOESIE}

Jacob and Wilhelm Grimm were bom in the late eighteenth century to a civil servant named Philipp Wilhelm Grimm and his wife Dorothea. Jacob, bom in 1785 , was the oldest of the nine children; Wilhelm was born a year later. After their father died in 1796, their lot in life changed dramatically, with Dorothea financially unable to raise her remaining six children without the help of her sister. As a student, Jacob was, because of his poor lot in life, addressed by the teachers with the less-respectful title "Er" instead of the respectful title "Sie". This was a definite humiliation to him and may have been the impetus for his later interest in the simple folk in their "Glaube, Sitte, Brauchtum, Recht, Kultur, Sprache" (Rölleke, Die Märchen 27-28).

The Grimm brothers lived in Germany during a time of political and social upheaval, due especially to Napoleon conquering Europe. Heinz Rölleke mentions that because of the turmoil within Europe, the Grimms intended to preserve German culture by recording a history of poetry, via Märchem.

Angesichts der europäischen Eroberungen Napoleons schien es seinerzeit dringend geboten, wenigstens die vaterländische Kultur in ihren mannigfachen Erscheinungsformen und Traditionen zu erhalten und zu pflegen. (Die Märchen 23) 
It was an important time to safely guard German culture by remembering the past before it was forgotten. The essence of reaching for past roots was the spirit of Romanticism, the period in which the Grimm brothers lived. Already familiar with the classic period of Goethe and Schiller, they got their first taste of the "Geist der Romantik" through instructor Friedrich Karl von Savigny's collection of books (Gerstner 13).

The Grimm brothers' association with Clemens Brentano and Achim von Amim also sparked their interest in old literature. Brentano and Arnim had their first Des Knaben Wunderhom published in 1805; this collection of songs reaches back to 300 years of lyrical Volk poetry. After the publication of the first volume in 1805, Brentano and Arnim wanted to continue collecting for their next volume of the Knaben Wunderhorn. Through their mutual friendship with Savigny, Jacob, Wilhelm and Ferdinand Grimm (brother of Jacob and Wilhelm) began helping collect not only Lieder but "alte deutsche Poesie" (Hetmann 83)

The Grimm brothers helped work on the second and third volume of the Wunderhorn collection. With the knowledge of collecting Volkslieder Jacob and Wilhelm gained experience in the art of collecting, which helped in their future works. Wilhelm wrote to Goethe about the importance of the Märchen, saying that they mark the "eigentümliche poetische Ansicht und Gesinnung des Volks" Gerstner 41). And to Arnim similarly: "Ich sehe täglich mehr ein, wie wichtig diese alten Märchen in die ganze Geschichte der 
Poesie eingreifen" (Gerstner 41). The Grimm brothers saw their collection as an important representative work for the folk.

The Grimm brothers were not the first German collectors of Märchen, nor were they the first to invent the word. In Middle High German literature the word "maere" appears in the sense of meaning "Nachrichten" or news. In, for example, Das Nibelungenlied from 1200 A.D., one passage reads "danken si began dem boten dirre maere" $(555,2-3)$, which means "she thanked the messenger for the news (maere)". Similarly, in 1539 Martin Luther used the phrase "gute neue Mä(h)r" in his Weihnachtslied to mean message or news of an event or truth (Röllecke, Die Märchen 9).

German contemporaries of the Grimm brothers published various Märchen collections. Johann August Musäus published his Volksmärchen der Deutschen (1782-86); Christian Wilhelm Guenther produced Kindermärchen aus mündlichen Erzählunger, Benediktc Naubert published Neue Volksmärchen der Deutschen (1789-93); in 1809 Kindermärchen by Albert Ludwig Grimm (who was not related to the Grimm brothers) and Volksmärchen by Ludwig Tieck appeared; and in 1812, a few months before $K H M$, the German scholar Johann Gustav Büsching published his collection Volkssagen, Märchen und Legenden. Another in the field of collecting fairy tales was Ludwig Bechstein (1801-1860), who in 1845 published his Deutsches Märchenbuch.

However, the popularity of the Grimm brothers lasted into the twentieth century; they seem to have a universal appeal in their 
collection of tales. In the Vorrede of the 1812 edition of the $K H M$, the Grimms summarize the reason for the widespread dispersal of their fairy tales:

Weil diese Poesie dem ersten und einfachsten Leben so nah liegt, so sehen wir darin den Grund ihrer allgemeinen verbreitung, denn es gibt wohl kein Volk, welches sieganz entbehrt. (qtd. in Schmitt 140) The Grimms felt the reason for the universal appeal of their Märchen was the way they related so closely to life.

The Grimms are considered the inventors of the science of folklore, as Linda Dégh asserts:

The Grimm brothers were primarily scholars-linguists, historians of religion and literature, and students of customary law. Nlthough their nationalistic vocation was obvious, the comparative method opened up a new chapter in philology. They established a new discipline: the science of folklore. Their example of collecting oral literature launched general fieldwork in most European countries and resulted in the cooperative scholarly study of their prime focus of interest: the Märchen. (87) Indeed, the Grimm brothers' collection of Märchen became that which is a standard not only for German fairy tales but for fairy tales in general. Andre Jolles in 1930 called this Grimmian phenomenon the "Gattung Grimm": 
Die Grimmschen Märchen sind mit ihrem Erscheinen, nicht nur in Deutschland sondem allerwärts, ein Maßstab bei der Beurteilung ähnlicher Erscheinungen geworden. Man pflegt ein literarisches Gebilde dann als Märchen anzuerkennen, wenn es--allgemein ausgedrückt--mehr oder weniger übereinstimmt mit dem, was in den Grimmschen Kinder--und Hausmärchen zu finden ist. Und so wollen auch wir . . . von der Gattung Grimm sprechen. ( Rölleke, Die Märchen 36)

As to this "Gattung Grimm," the question has been asked, is it the voice of the Volk or of the poet-."Volksmärchen" (folk tales) or "Kunstmärchen" (literary fairy tales). Both "subgeneres" appear in the Grimms' Märchen collection (Bottigheimer 8). The Grimm brothers were clear on how they viewed their collection; they made "repeated assertions that these tales welled up from the people and represented a 'natural poetry' (Naturpoesie)" (Bottigheimer 12). Achim von $A$ rnim saw himself more as a poet. The difference between Naturpoesie and Kunstpoesie can be traced back to the theme of nature. In comparing the Grimms with Arnim and Brentano, Hermann Gerstner remarks in his Grimmian biographical work about the love for nature that the Grimm brothers had. He compares them with their "Dichterfreunden":

So wie sie in ihrem Alltag immer gern in die Natur hinaus wanderten, gingen sie auch literarisch gern mit 
dem naturnahen Volk um. Es war eines ihrer frühesten Anliegen, das vom Volk erzählte dichterische wort zu bewahren. Dort lebten vielfach noch die alten Geschichten weiter, die als Märchen über Länder und Jahrhunderte gezogen waren . . . A Aber im Gegensatz zu ihren Dichterfreunden wollten Jacob und Wilhelm nicht eigene dichterische Werke aus der Überlieferung her gestalten; vielmehr ging es ihnen darum, das was das Volk sich erzählte, so echt und schlicht wie möglich zu bewahren. (38)

Just as the Grimm brothers enjoyed the simplicity of nature, so too they desired to keep the poetry of the folk in its natural form. In contrast, Brentano and Arnim were poets who created their own works.

Despite the inevitable universal appeal of the Grimm collection of fairy tales, the German nationalistic purpose of the Grimm brothers was no secret. The political and social upheavals in Germany at the time made them aware of the need for a German identity. The Grimm brothers started collecting Märchen at the same time as the "Doppeltschlacht von Jena and Auerstedt" in 1806. The order of society was destroyed as thousands of soldiers, villages and houses were burned. In the midst of this turmoil, the two brothers began rescuing what they could find of a German spirit, before it was forgotten (Gerstmer 38). Jack Zipes further explains the 
political and social situation in which the Grimm brothers found themselves in during their early twenties:

Der Wunsch . . . bestand darin, ein Werk zu veröffentlichen, aus dem deutscher Geist sprach und so zu einer vereinigten Front aller Deutschen gegen die französische Besatzungsmacht beizutragen. Die Grimms fühlten sich auch als Teil eines gerade sich bikdenden nationalen Bürgertums, das versuchte, seine eigene deutsche Identität auf mehr demokratische Art und weise zu begründen, im widerspruch gegen die aristokratischen Cliquen, die die an die $\mathbf{3 0 0}$ deutschen Kleinstaaten regierten. (Hetmann 88)

The Grimm brothers were part of a movement to build a German identity. Herman Grimm, who was the son of Wilhelm Grimm, describes his father's plan simply: "Ihr Trieb war, zu sammeln, was als Denkmal des deutschen Geistes erreichbar wäre" (17). They were looking to establish a representative voice of the German spirit in literature.

The first volume of Kinder-und Hausmärchen was published in Berlin in December of 1812 . The second volume came in 1815 . The second edition was published in 1819 with some changes, including new stories and revisions of the old. Between 1812 and 1857 there were seven large and ten small editions of the $K H M$, with changes, reworkings, deletions, amplifications, and adaptations. 
One needs to ask: why were there changes and adaptations? Does this contradict the idea of preserving the original voice of the Volk in a "true" way? As Johannes Bolte and Georg Poliv́ka point out in their Anmerkungen zu den KHM.

Die Aufzeichnung soll in Mundart, Redensweise und Wendung des Erzählenden geschehen, selbst wo solche fehlerhaft und sich gegen die Regeln versündigend erscheinen. (4:424).

Nonetheless, the brothers Grimm did have their own distinct Märchen style in which they compiled all the fairy tales into a unified one (Dollerup 262). And Rölleke points out:

Grimms Märchen selbst wären nicht der größte deutschsprachige Bucherfolg aller Zeit geworden, wenn nicht aus dem Magma der Volksüberlieferung damals so behutsam ausgewählt, so stilsicher zusammengestellt, überarbcitet und weitererzählt worden wäre.

(Dic Märchen 62)

Through these changes Wilhelm Grimm was creating his own fairy tale style. One can see the conflict which Jacol) Grimm and Arnim had over Volks-and Kunstmärchen in a letter exchange between the two men in $1812 / 1813$. Wilhelm Grimm did not seem to have a problem reconciling the two:

So gelang es Wilhelm Grimm in der Praxis mit wachsendem Erfolg, diese Spannung allmählich auszugleichen. Durch Kontaminationen und Einbringung 
Zahloser volksläufiger Redensarten rundete er die Einzeltexte zu sinnvoll und geschmeidig erzählten kleinen Kunstwerken sui generis; durch den immer vollkommener gelingenden versuch, eine volks-und kindertümliche Sprache einzubringen . . . schuf Wilhelm Grimm den unverwechselbaren Stil des Grimmschen Buchmärchens. (Rölleke, Die Märchen 79) The Grimm brothers emphasized their faithfulness to the voice of the Volk as they recorded their Märchen, continually stating that their collection of Kinder-und Hausmärchen represented German spirit. They believed their work was Naturpoesie, that is, natural poetry from the Volk.

As stated in the above Rölleke quote, the Grimms wanted to bring a "volks-und kindertümliche Sprache" into their collection of tales. This brings one back to the question of children and fairy tales, a question that has been simmering since the first $K H M$ publication in the nineteenth century. 


\section{CHAPTER II}

\section{CHILDREN AND FAIRY TALES: REASONS FOR THEIR IMPORTANCE: FOUR VIEWS}

When one talks to people about various Grimm fairy tales, an element of shock is evident in their responses. For example, when one mentions that the stepsisters in "Aschenputtel" used a knife given to them by their mother to cut off parts of their feet to fit into the lost shoe, parents are quite surprised at such gruesomeness in a story for children. The natural doubt that arises is the appropriateness of these kinds of fairy tales for children.

Jacob admits that the original intention may not have been to create a literature genre for children; his letter to his friend Arnim explains his view on children and fairy tales:

Das Märchenbuch ist mir daher gar nicht für Kinder geschrieben . . . aber es kommt ihnen recht erwünscht, und das freut mich sehr . . . Diese Märchen wohnen darum bei Kindern und Alten. (Gerstner 42) Wilhelm also writes to Arnim that he foresaw the criticism that was to come, but still defended the collection, as one would defend the use of the Bible:

Den Einwurf, daß manche es nicht getrauen, ihren Kindern das Buch in die Hände zu geben, habe ich voraus gesehen, indessen ist das nicht zu ändern . . . Wir haben z.B. zu Haus die Bibel gelesen, jeden Abend ein Kapitel, es sind doch viele Stellen darin, die wohl mancher ängstlich zurückhalten würde. (Gerstner 43) 
In the second edition of the $K H M$ the Grimms address their critics. They mention how they made a special effort to eliminate any childoffensive material, and that if parents are still offended with certain sections they can make careful selections. But they do emphasize that on the whole this is unnecessary (1819 Vorrede KHM 31 ). Jacob and Wilheim further affirm the merit of their work for children:

Nichts besser kann uns verteidigen als die Natur selber, welche diese Blumen und Blätter in solcher Farbe und Gestalt hat wachsen lassen; wem sie nicht zuträglich sind nach besonderen Bedürfnissen, der kann nicht fordern, daß sie deshalb anders gefärbt und geschnitten werden sollen. Oder auch, Regen und Tau fällt als eine Wohltat für alles herab, was auf der Erde steht; wer seine Pflanzen nicht hineinzustellen getraut, weil sie zu empfindlich sind und Schaden nehmen könnten, sondern sie lieber in der Stube mit abgeschrecktem Wasser begießt, wird doch nicht verlangen, dal3 Regen und Tau darum ausbleiben sollen. Gedeihlich aber kann alles werden, was natürlich ist, und danach sollen wir trachten. (31) This poetical analogy of comparing fairy tales to leaves and flowers and rain and dew defends the naturalness of Märchen, which ties them closely to nature, a Romantic characteristic.

Several factors led to the $K H M$ becoming a work specifically for children, not just a history of poetry that could be used for 
children. Timing, marketing and child-culture played roles in the success of the $K H M$ as literature for children. Maria Tatar points out in her book, Off With their Heads, "Fairy tales began to reach print at just the point when a real commercial market was developing for children's literature" (8). The rise of a middle class with money to buy books lead to a reading public. The 1825 small edition was specifically aimed at the market of literature for children. Kurt Stiasny in his book analysis, Was Grimmische Märchen erzählen. Original und Deurung, explains the child-culture, and how one needs to look at the social development of the nineteenth century to see one of the reasons for the success of the $K H M$. He aptly summarizes:

Daß die Herausgeber im Titel die Lesergruppen eingrenzten, lag wohl am sozialgeschichtlichen Hintergrund: Denn der Siegeszug dieser Märchen ist zu erklären einerseits aus der wachsenden Kraft des Bürgertums und seines von ihm gepflegten Familienlebens, andererseits aus der Verehrung des Kindes insbesonders in der Romantik. So wurde die Sammlung im 19. Jahrhundert das Vorlesebuch für Kinder, keine Lektür, das betonen die Herausgeber, für Verbildete. (18)

Wilhelm stated clearly his belief in the possibility of the collection of stories being an "Erziehungsbuch," an educational manual. In the Preface of the 1819 edition, the brothers discuss the reasons for 
collecting their stories, and the various purposes the fairy tales have. The $K H M$ is clearly not only a history of poetry, "sondern es (war) zugleich Absicht . . . daß die Poesie selbst, die darin lebendig ist, wirke und erfreue, wen sie erfreuen kann, also auch, daß es als ein Erziehungsbuch diene" (30).

To Savigny, wilhelm expressed his belief clearly about the use of the $K H M$ as an educational manual: "da ich mir nichts ernährender, unschuldiger und erfrischender weiß für kindliche Kräfte und Natur" (Gerstmer 43). Jacob expresses caution at the same time: "Freilich sollte man den Kindern nicht zuviel auf cinmal, sondern nach und nach immer einen Brocken dieser süßen Speise geben" (Gerstner 42). In Kindenwelt Märchenwelt D. Udo Haes compares the function of Märchen with the use of herbs in times past:

Und so dürfen wir ruhig sagen, daß ebenso wie für jede Krankheit ein Kraut gewachsen ist, auch für jedes gesunde Verlangen, jeden gesunden Entwicklungsimpuls eines Kindes ein Märchen gewachsen ist, das ihm die dafür nötige Seelennahrung verschafft. Dieses Märchen ist dann das 'Brot' für seine Seele. (95)

Terms such as "Brot für Seele" and "süße Speise" connote something good, something tasteful, and something nourishing. Several different reasons have been given for the importance of fairy tales and why they have been considered "bread for the soul" 
or a "sweet dish for children". First of all, fairy tales express the view of the child, by presenting a child-like world view. As quoted above, the Grimm brothers felt that fairy tales captured "den reinen Gedanken einer kindlichen Weltbetrachtung" (Vorrede Deutsche Sagen 8). Linda Dégh agrees:

The tale speaks the language of childhood fantasy. Its world view corresponds with the world of the child . . . . The tale takes place in the 'once upon a time' never-never land,'. . The small child's world view is magic, not yet filled with rationality. (99-100)

This child-like world is a world where reason is not needed and where wishing still helped-."wo das wünschen noch geholfen hat." One idea behind this concept is that reality and imagination have not conflicted yet for a child. Wishes coming true are still possible. Similarly, Gottfried Herder (1744-1 803) felt that children "should be taught the 'natural language' of the Märchen early, along with the mother tongue" (Dégh 92). Kurt Stiasny quotes the view of Christa Meves who defines the natural essence of fairy tales to be the mother tongue of the soul of the child: "Die Märchensprache ist daher für sie keine Fremdsprache. Sie ist die Muttersprache ihrer Seele" (10). Because fairy tales are said to express a child-like world view, children grow up naturally understanding them as they do their spoken language. Fairy tales are therefore considered to be a child's native tongue. 
Not only do fairy tales present a child-like world view, but they are also intrinsically liked by the child. In Ellwanger and Grömminger's book, Märchen--Erziehungshilfe oder Gefahr?, the way children are naturally drawn to Märchen is emphasized:

ES läßt sich leicht beobachten, welche hohe Aktualität das Märchen für unsere Kinder hat. Das starke Verlangen danach und das zwingende Bestehen auf Wiederholung immer wieder derselben Märchen in unveränderter Darstellung weisen auf den 'inneren Realitätsgehalt', den das Märchen für das Kind besitzt, und geben darüber hinaus wertvolle diagnostische Hinweise auf die innerseelische Situation des Kindes und seine Auseinandersetzung mit Welt und Umwelt. (15)

The inevitable liking that children have for fairy tales has been reason enough for some to say that Märchen are good for them. Some have gone so far as to say that children and fairy tales are inseparable. In his book Kindenvelt--Märchenwelt, D. Udo Haes remarks:

Wir suchen das kleine Kind und mit inm die Märchen. und suchen sie beide als lebendige Wesen, die untrennbar zusammengehören, die als 'Zwillingspaar' geboren, aber als ein Wesen großgezogen werden müssen. (1 19) 
The inevitable effect that Märchen have on children is also a reason given for the importance of fairy tales. With stories about princes, faithful servants, millers, kings, and poisoned apples come an enormous opportunity for children to re-create the tales by acting out the various parts. Ellwanger and Grömminger explain:

Das Märchen mit seiner Vielzahl phantastischer Elemente fordert den Rezipienten (Hörer oder Leser) dazu heraus, diese zu reproduzieren, d.h. mittels der Fähigkeit, Phantastisches vorstellungsmäßig zu verwirklichen, ein Bild davon zu bekommen und sie verarbeiten zu können. . . Phantasietätigkeit ist erzieherisch zu beeinflussen. (78)

Edgar Taylor, who in 1823, translated the first English version of Grimms' fairy tales, titled German Popular Stonies, agrees that fairy tales are important for the imagination of the child:

In contrast to the 'prudery and artificial taste' of the previous century the time had come to welcome the aera when our children shall be allowed once more to regale themselves with that mild food which will enliven their imaginations, and tempt them on through the thorny paths of education.' (Alderson 64)

The way fairy tales broaden the child's imagination, are intrinsically liked by children, and present a child-like world view are various reasons given for the validity of fairy tales for youngsters. 
Another, the idea that Märchen allow children to see that evil can be conquered, has been given as explanation as well:

Häufig können wir beobachten, wie Kinder auch die Märcheninhalte, . . . in ihre Spiele übernehmen und sich so, wie Freud sagt, 'zu Herren der Situation' machen. In solchen Fällen kommt dem Märchen dieselbe Funktion wie dem Spiel zu: Mittel zur Bewältigung von Konflikten zu sein. (Ellwanger and Grömminger 31)

Fairy tales teach that one can overcome an unfair situation, and that no matter how bad it is in the present time, one needs to be patient and eventually one can overcome evil.

The lesson in many fairy tales, that good will prevail and evil will be punished, is the concept of justice. Fairy tales present a world that is just, a workd of order. a world that has a definite good and bad---a black and white world, a world of extremes. That leads to another benefit of fairy tales for children. The Grimm brothers in their Vorrede of their $1812 K H M$ remark:

Alles schöne ist golden und mit Perlen bestreut, selbst goldne Menschen leben hier, das Unglück aber eine finstere Gewalt, ein ungeheurer menschenfressender Riese, der doch wieder besiegt wird. . . . Das böse auch ist kein kleines, nahstehendes . . sondern etwas Entsetzliches, Schwarzes . . . ebenso furchtbar die Strafe desselben: Schlangen und giftige Würmer 
verzehren ihr Opfer, oder in glühenden Eisenschuhen muß es sich zu Tod tanzen. (qtd. in Schmitt 139)

Mieder in his book elaborates how, certain emotions are found in "contrasting pairs" where, for example, wealth versus poverty, or kind-heartedness versus meanness are portrayed. This "black and white" world has its conflict resolved in the end (Tradition and Innovation 2-3). The idea that problems are eventually resolved is the essence of justice. The punishment of evil is its core. The idea follows that when there is justice in the world, there is also order, which the child comes to conclude on his own through the reading of Märchen:

Das Märchengeschehen wird von Grundanliegen und Urthemen des menschlichen Daseins bestimmt. Der Wunsch nach Glück und Erfolg, nach Ordnung und Gerechtigkeit, nach Liebe und Gemeinsamkeit, die Verstrickung in Neid, Habgier und Bösheit resultieren in den im Märchen üblichen Ausprägungen aus jenen kontrastierenden verfahren. Durch die Absolutheit der Darstellung vermag das Kind Ordnungsprinzipien zu erkennen, welche in menschlichen Leben wirksam sind. Der Hörer erlebt Recht und Unrecht in extremer Form. (Ellwanger and Grömminger 76)

The contrasts that children see in fairy tales teach them the difference between good and bad, and that justice will conquer in the end. Fairy tales normally have a happy ending, which is good 
for the child. Without a positive ending in a story, a child can sense the message that something is wrong with the world, and this can hurt his development (De Haes 105). Isaac Bashevis Singer in his article, "On Writing for Children," relates how important it is for a child to get the sense of justice in the world:

If you tell a child that a murderer or a thief was never punished and never caught, the child feels that there is no justice in the world altogether. And I don't like children to come to this conclusion, at least not too soon. (12-13)

Seeing justice in the world helps give the child a start to viewing life optimistically. Wolfgang Mieder mentions how, through the optimistic world view of the fairy tale, children "realize and understand human problems, which in turn will be a key to coping with their own individuality and the world at large" (Tradition and Innovation 2).

Fairy tales inspire children to face all that living holds, both the good and the bad. In Kindenvelt-Märchenwelt, de Haes explains the belief that fairy tales help people find a way through inevitable darkness:

Sie zeigen ihm den Lichtweg durch die Finsternis, den es in seinem Leben gehen muß, und sie fügen es zugleich--wie auch die Erwachsenen--unbemerkt cin in die große Menschheitsentwicklung und machen sie in diesem Sinne zu wahren Weltbürgern. Sie sind, jedes 
auf seine Weise, eine kleine Bibel, Altes und Neues Testament zusammen, gezeichnet in Farben, denen das Herz des Kindes offensteht. Sie sind die wahre, bilderreiche 'Kinderbibel'. (14)

"Bilderreich" means symbolic. Many scholars and parents believe that one can read much in the Märchen of the Grimm brothers and other fairy tale collections symbolically. "Die Sprache der Märchen bestcht, soweit die Märchen erzählt oder gelesen werden, aus Worten, aber sie ist nicht in jedem Falle auf diese Worte angewiesen. . . . Sie beseht ebenso aus Bildern" (Ellwanger and Grömminger 39). And:

Wer aber die Bildersprache der Sprichwörter versteht, begreift, daß sie nicht buchstäblich genommen werden will, sondern sinnbllallich eine Wahrheit hinsichtlich des Menschen zum Ausdruck bringt. (de Haes 7)

Max Lüthi, in his book Fairytale as Art Form, describes symbolism clearly, when he mentions how one can view the negative figures in the Märchen:

Especially dragons, monsters, and witches, as representations of evil itself--for the child they are the personifications of evil. And evil must be combated and defeated, a notion in accord with the ethics of not just the child. (153-154) 
For example, when one analyzes the punishment of the witch in the story of Hänsel and Gretel, one sees an act of extreme cruelty. Buming a person, good or bad, in an oven, seems shocking, especially in a story for children. But, as Mieder points out, one needs to view the act as "but one symbolic step in dealing with an evil force and a way toward liberation and independence" (Tradition and Innovation 36).

Some feel the ability to think symbolically is inherent in a child (Ellwanger and (Grömminger 36), while the adult tends to think rationally, realistically, and al)stractly. Mieder points out how adults:

Understand fairy tales critically rather than symbolically. Having relinquished their naive dreams of a perfect world of happiness, love, and optimism, they often question the positive value of the fairy tales . . . they are too occupied with real-life problems. (Tradition and Innovation 5-6)

Joseph Campbell comments on the symbolic clements in tales, comparing them with the myth. He sees the fairy tale as representative of not only children but of all human experience:

For, whereas the symbolic figures of mythology were regarded . . not as symbolic figures at all but as actual divinities to be invoked, placated, loved and feared, the personages of the tale were comparatively insubstantial . . . Hence when the acids of the modern spirit dissolved the kingdoms of the gods, the tales in 
their essence were hardly touched . . . . So that we may say that out of the whole symbol-building achievement of the past, what survives to us today is the tale of wonder. The tale survives, furthermore, not simply as a quaint relic of days childlike in belief. Its world of magic is symptomatic of fevers deeply burning in the psyche: permanent presences, desires, fears, ideals, potentialities, that have glowed in the nerves . . . since the beginning . . . . History is the promise of Märchen realized through, and against the obstacles of, space and time. (863)

The clefense that Campbell makes for the "ageless" fairy tale leads him to summarize: "The folk tale is the primer of the picturelanguage of the soul" (864).

While there are many reasons for the importance of fairy tales for children--they present a child-like world view by speaking a natural language understood by the child; they are inherently liked by children; they influence the imagination; they show that evil can be concuered; and they show a world of order and justice--two reasons stand out among scholars and parents for the disadvantage of fairy tales for children: social stereotyping and violence.

The first one will be touched on only briefly. The typical societal roles portrayed in fairy tales are often criticized. The concern is summarized in Ellwanger and Grömminger's book, Märchen-Erzichungshilfe oder Gefahr?: 
Das dargestellte Weltbild mit Königen, Prinzessinnen, Oberen und Untertanen, das Verhältnis von Mann und Frau behindert beim Kind die Ausbildung einer wirklichkeitskritischen sicht . . . die stereotypen ... welche im Erziehungsprozeß eine ungünstige Sozialisationsfunktion ausüben. (16) Joseph Campbell has no problem with the societal stereotyping, believing that the fairy tale is the "story our spirit asked for":

Playful and unpretentious as the archetypes of fairy tale may appear to be . . . all are working in order that the ungainsayable specifications of effective fantasy, the permanent patterns of the tales of wonder, shall be clothed in flesh and known as life. And so we find that in those masterworks of the modern day which are visionary, rather than of a descriptive order, the forms long known from the nursery tale reappear, but now in adult maturity . . . Wagner . . his Ring of the Nibelung, Strindberg and Ibsen their symbolic plays, Nietsche his Zarathustra. Melville his Moby Dick. Goethe . . . his Faust. (863-864)

Children, and, as Campbell asserts, adults, enjoy being transformed into a world of make believe, where knights and princes and queens reigned, and "wo das wünschen noch geholfen hat." 


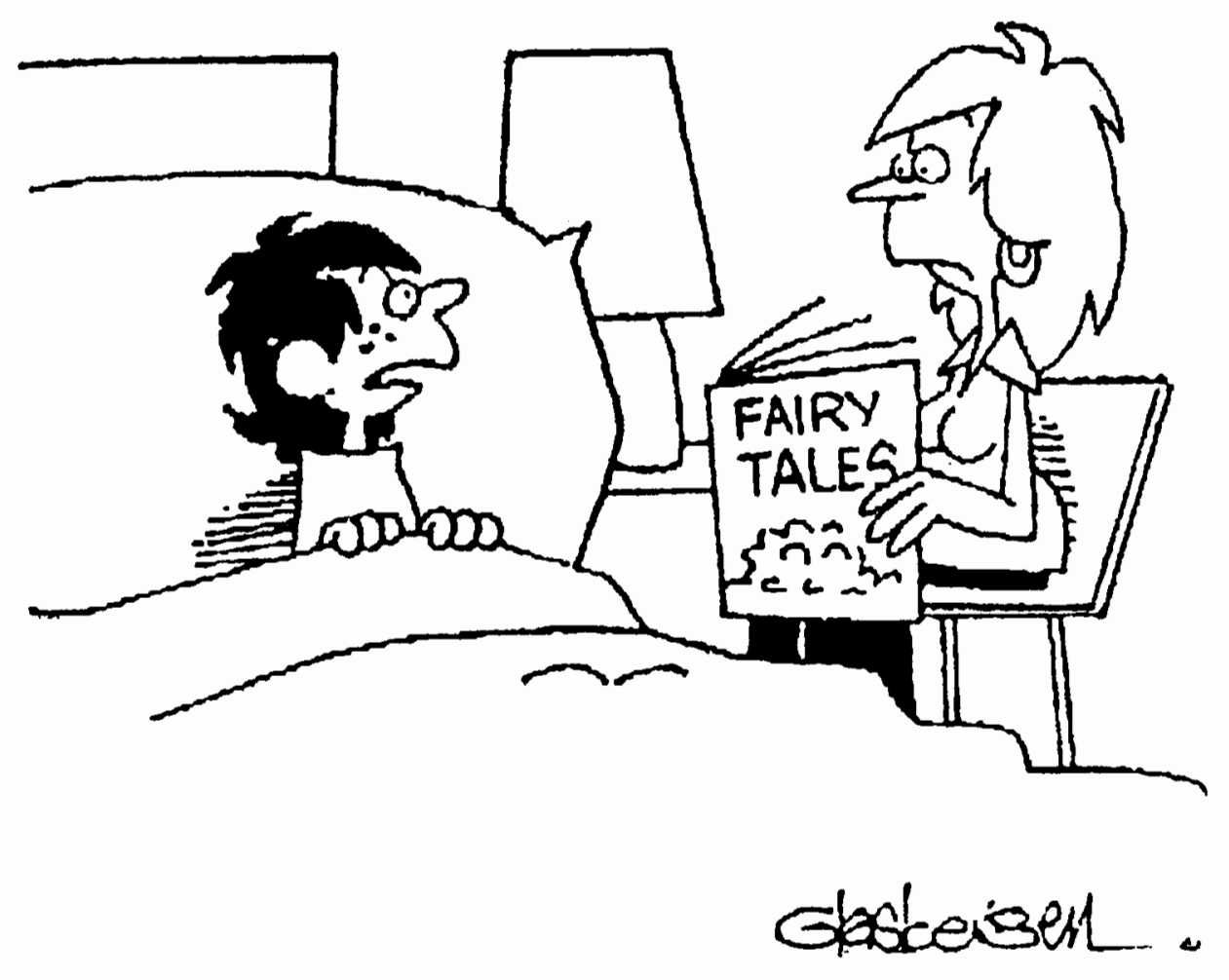

"Witches poisoning princesses, giants falling off beanstalks, wolves terrorizing pigs . . . and you complain about violence on TV!?" (reprinted in Mieder. Tradition 92)

The other criticism of fairy tales, that they are too gruesome for children, is worth deeper analysis, as one can see from the above comic. One cannot simply defend fairy tales and the evident violence in then with the words: "They're just fantasy." Critic Pickard, in his I Could a Tale Unfold: Violence in Fairy Tales, asks the question directly: "Do children need horror in stories? If so, how much and how soon?" (1). That question has been asked often by fairy tale scholars. Linda Dégh emphasizes, especially when related to Grimms tales, how: 
The most commonly voiced concern still remains the fearsome, gruesome nature of the Grimm tales. In our age, there is more reason than ever to consider the question: are not children's tales . . . as some believe, the propaedeutics of all that is subsumed under the title of violence? (97)

Critics of violence in literature for children do not give leeway to fairy tales any more than to other types of literature. Max Lüthi wonders if the violence found in fairy tales can encourage aggression in children (The Fairytale as Art Form 152). Some think that accusation is extreme. Mieder notes how when people are unwilling to accept some of the symbolic nature of fairy tales, they will "emphasize the gruesome isolated scenes" (Tradition and Innovation 36-37). In the story "l länsel and Gretel," for example, one can view when the witch is put into the oven in two different ways: symbolically or literally. If one views it symbolically, one focuses on the general idea that evil, in this case the witch, is destroyed; that is, the story portrays a world of order where justice is done. However, if one focuses entirely on the literal event of a person, albeit evil as the witch was, being thrown into an oven, one might criticize the gruesomeness of the event. It should be noted that often the violent elements evident in fairy tales are in the form of punishment of evil. Another Grimm story with extreme punishment of the villain is titled "Die sechs Schwäne." In this fairy tale the wicked mother-in-law is burned at the stake for stealing the children 
of her daughter-in-law and falsely accusing her of murder. This fairy tale shows that there are extreme consequences for evil actions, in this case stealing children and falsely accusing an innocent person. And in the fairy tale, "Der singende Knochen," the older brother, who murdered his younger sibling, is placed in a bag and drowned as punishment. These cruel retaliations towards evil forces are representative of Grimm fairy tales, and go back to the concept of justice: evil must be punished. By the nature of the extremes in fairy tales, the rewards are to live happily ever after, while the punishments are the other extreme--cruel and painful. Max Lüthi explains:

Instances of cruelty often appear in the fairytale, principally in the form of cruel punishments. That is a consequence of the particular stylistic tendency of the fairytale toward the extreme. A princely reward or a sentence of death is but one of the many contrasts used in the fairytale. (Fairytale as Art Form 152)

The style of fairy tales to have extreme consequences for actions is part of what make up the genre, the genre the Grimms in essence created.

Tatar notes in her book, Off with their Heads, how fairy tale collectors "justified the display of cruel punishments on both pedagogical and moral grounds" (31). But many people, both scholars and parents, disagree with the violence in Grimms' 
Märchen and see no pedagogical basis for its use in educating children.

The basic question of the usefulness of Märchen for children has been debated since the Grimm brothers had their collection first published in 1812 . Since that time, people have fallen into four camps on the issue of Grimm fairy tales and children: those who 1) read them as they are in their entirety to children; 2) don't read them at all; 3) make careful selections based on age-appropriateness; and 4) adapt them.

The original intention of the Grimm brothers was to not change anything in their text, because they wanted to remain truc to the spirit of the Volk. They state their effort clearly in the Vorrede to the 1812 edition:

Wir haben uns bemüht, diese Märchen so rein, als möglich war, aufzufassen . . . . Kein Umstand ist hinzugedichtet oder verschönert und abgeändert worden, denn wir hätten uns gescheut, in sich selbst so reiche Sagen mit ihrer eigenen Analogie oder Reminiszenz zu vergrößern, sie sind unerfindlich. In diesem Sinne existiert noch keine Sammlung in Deutschland, man hat sie fast immer nur als Stoff benutzt, um größere Erzählungen daraus zu machen. die willkürlich erweitert, verändert, was sie auch sonst wert sein konnten, doch immer den Kindern das Ihrige aus den Händen rissen und ihnen nichts dafür 
gaben. (qtd. in Schmitt 142)

They emphasized that their fairy tales were not created but recorded in a pure manner, uninhibited with changes. In the 1819 preface of the $K H M$ the Grimm brothers elaborated on the idea of keeping the stories pure, but realized:

Daher ist der erste Band fast ganz umgearbeitet, das Unvollständige ergänzt, manches einfacher und reiner erzählt, und nicht viele Stücke werden sich finden, die nicht in besserer Gestalt erscheinen. (34)

At first glance there seems to be a contradiction in the goal of the Grimm brothers as they updated from the 1812 to the 1819 edition of their collection. But actually, the reasons they changed their intentions fall mostly under the umbrella of form. They wanted to eliminate sentence fragments; to conform to a style that reflects the Volk, to reflect Volk life; to flavor the tales with figures of speech; and to add proverbs to decorate the language. And, realizing the popularity of their work for children, they deleted "jeden für das Kindesalter nicht passenden Ausdruck in dieser neuen Auflage" (Vorrede $1819 K H M 31$ ). Despite these types of reworkings, the Grimm brothers claimed to remain true to the spirit of the Volk they collected the stories from:

Was clie Weise betrifft, in der wir hier gesammelt haben, so ist es uns zuerst auf Treue und Wahrheit angekommen. Wir haben nämlich aus eigenen Mitteln nichts hinzugesetzt, keinen Umstand und Zug der Sage 
selbst verschönert . . . daß der Ausdruck und die Ausführung des einzelnen großenteils von uns herrührt, versteht sich von selbst, doch haben wir jede Eigentümlichkeit, die wir bemerkten, zu erhalten gesucht, um auch in dieser Hinsicht der Sammlung die Mannigfaltigkeit der Natur zu lassen.

(Vorrede 1819 KHIM 34-5)

Although the reworkings between editions of the $K H M$ were evident, the Grimm brothers strongly defended their Märchen and their use for children. They highly recommended their collection of tales be read in its entirety. True to the spirit of the Grimm brothers, some believe that the Kinder-und Hausmärchen should be read and told without any changes at all. P.L. Travers, sees the problem with changes in fairy tales. She comments on how fairy tales have been: Bowdlerized and had the essentials removed in order not to frighten--but to my mind it is better not to tell them at all than to take out all the vital organs and leave only the skin. And what isn't frightening, after all? What doesn't carry a stem lesson. Even nursery rhymes present us with very difficult truths . . . Take Humpty Dumpty. All the king's horses and all the king's men couldn't put him together again. That some things are broken irrevocably, never to be whole again, is a hard truth. (196-197) 
Travers seems to be suggesting that the harsh reality in stories is a part of life that children need to leam. Hornyansky agrees in his essay, "The Truth of Fables":

We should see once and for all the foolishness of any attempt to tamper with such tales, to pretty them up so as not to shock tender minds. I myself should prefer to take them unaltered, as a guide to bringing up children sensibly. (131)

The changes that beautifying a story bring are different from the kind of improvements the Grimm brothers made in the area of form or style. Writer of children stories and American filmmaker Walt Disney has been accused of a kind of reworking of original fairy tales that has lead to some critics calling his works silly. Hornyansky believes the best tales are those that one projects: Honestly, without any sentimental tidying up of the landscape. They do not distort the truth by filling the forest with cute, lovable little singing animals and motherly trees, in the manner of so many Disney cartoons. (124)

Hornyansky suggests that one should not try to cover up the reality of real life by adding visual distractions, as Disney has been accused of doing.

When Kay Stone sent out questionnaires to twenty-five modern-day storytellers, asking them various questions regarding Grimms' fairy tales in their work, four of them specifically mentioned 
one of the most gruesome of the Grimm fairy tales, The Juniper Tree." Two particularly influential storytellers, one of whom happens to be a therapist, believe that "The Juniper Tree," which includes murder and cannibalism, is fine if not good for children: "Children need the violence in folktales to help them understand and articulate their own lives, which include at least the awareness of violence" (Stone, Once Upon a Time Today 262). Within Stone's study of modern storytellers, only one who was interviewed took the extreme position on Grimm fairy tales, that of not telling them at all. Elizabeth Nash, of Winnipeg, "rejected the Grimms completely on the basis of violence." She reflects:

I don't remember ever telling a Grimm story. . . . The brutality of some of the stories shakes me even now; the community that drove spikes into a barrel, forced an old lady into it and rolled it down the hill; the gang that heated iron shoes red hot, jammed them on an erring woman's feet and made her dance until she dies. This child was distressed to tears by them on more than one occasion, and possibly that's why this adult has not told Grimm stories. (Stone, Once Upon a Time Today 259)

The middle ground between banning Grimm stories altogether and taking them completely unaltered is the belief that one should use caution with fairy tales, such as picking out age-appropriate ones. The Grimm brothers themselves, in the preface to the 1819 edition, address the issue of the appropriateness of their collection 
for certain children, and quickly give parents a remedy: "so mag für einzelne Fälle die Sorge begründet sein, und sie können dann leicht eine Auswahl treffen" (31). As with other decisions that parents make for their children, choosing appropriate fairy tales seems to be a wise choice, especially selections that are appropriate related to the age of the child. D. Udo de Haes sums up the importance of using caution, especially exercising discretion with the younger listeners: "Vor allem, wenn das Kind noch sehr klein ist (drei, vier Jahre), ist es ratsam, sich in der Anzahl der zu erzählenden Märchen zu beschränken" (99). Lüthi says it well when he states that it is "wise to exercise discretion, both in the choice of fairytale and in the way that it is presented" (Fairytale as Art Form 153).

The idea of exercising discretion when it comes to the way in which a fairy tale is presented leads to the issue of medium of presentation. Medium of presentation is one aspect of adaptation, the fourth way to deal with fairy tales and children. Using different ways of sharing a story, besides reading (or telling) it, adds a whole new perspective. How children react to a fairy tale depends on many things: the communicator; the actual content of the story; the way the story is presented--read; told; audiotape; movie; television (Ellwanger and Grömminger 70). The various mediums of presenting a story are ways that one adapts fairy tales.

Perhaps the most familiar film adaptations of fairy tales are the Walt Disney versions. Donald I laase sums up: " $\Lambda$ S Disney's animated fairy tales remind us, the medium of adaptation adds yet 
another dimension to the issue of reception" (11). And Kay Stone mentions in her article, "Three Transformations of Snow White," how alterations "are a natural result of transformations from one medium to another" (52). She goes on to talk about the Disney brothers (Walter and Roy) and how they:

Intended to reach a new audience with the now-familiar Grimm material by reinterpreting the story from print into film. While they made no false claims as to their source, the final film carried Walt Disney's name in place of the Grimms' (Walt Disney presents "Snow White and the Seven Dwarfs"). (52)

Disncy does give credit to Grimm at a later point. At the start of the video one can read first "Walt Disney presents Snow white and the Seven Dwarfs." The next segment then adds, "Adapted from Grimms' Fairy Tales." Disney has helped familiarize Grimm stories in the United States.

Although $\Lambda$ merica has a wide selection of well-made movies for children, especially Disney films, the same phenomenon is not evident in Germany. Wilfried Schneider, in his article on literature for children in various forms of presentation, expresses disappointment with the quality of German films available for children, and is not satisfied with the Disney versions that are shown in Germany. He summarizes the situation in Germany:

Und die Filme, die für Kinder noch gezeigt werden, sind in der Mehrzahl Kinderschnulzen dümmlicher Kitsch von 
Karl May. . . bis zu den Trickfilmen aus der Disney.Produktion. (345)

With different versions of fairy tales coming out in various film and book forms, the question of which rendition is most appropriate for children follows suit. There has been definite criticism of Grimm fairy tales being harsh, to which Pickard remarks in defense of the Grimms:

We should be much freer to express our virtuous indignation at the way in which nineteenth-century parents had allowed so many children to be scared out of their wits over Grimms' Fairy Tales, if mid-twentiethcentury parents had not done something remarkably similar . . . over the business of comic papers and the horrors in them. (94)

Degh argues along the same lines when she quotes an author who compares Grimm fairy tales with other discrepancies in modern life: "How about the horror movies and gangster pictures?. . . How about toy guns as Christmas presents? Aren't they more damaging than Märchen witches?" (101) And in Kindenwelt-Märchenwelt D. Udo de Haes speaks of violence in literature for modern youth, thereby concluding that Grimm Märchen are no worse:

Viele Erwachsene, die Bedenken haben wegen der vermeintlichen Grausamkeiten und anderer 'Unmoralitäten' in den Volksmärchen, werden nichts dabei finden, ihre Kleinen die Kindergeschichten in den 
Zeitschriften lesen zu lassen oder sie ihnen selbst vorzulesen. Jeder kennt sie, die in immer neuen Variationen auftauchenden 'Helden' und 'Abendteuer' der modernen Jugendliteratur. (57)

The Grimm brothers never apologized for including severe consequences for unacceptable behaviors in their collection of fairy tales. Extreme punishments for evil people were as natural to them as were beautiful rewards for good people. Reward and punishment are part of the contrasting elements that define fairy tales in their essence. The Grimm brothers, as quoted above, described the extremes in the Vorrede to the $1812 \mathrm{KHM}$.

Das Böse auch ist . . etwas entsetzliches, schwarzes . . . ebenso furchtbar die Strafe desselben: Schlangen und giftige würmer verzehren ihr Opfer, oder in glühenden Eisenschuhen muß es sich zu Tod tanzen. (qtd. in Schmirt1 39)

The extremes that the Grimm brothers included in their fairy tales were a natural part of what they felt Märchen were to be made up of. Violence was not their concern. A poem entitled "The Benefactors" by Sara Henderson Hay summarizes the general characteristic that Grimm fairy tales have, and are known to have. that of including definite punishment for evil, or as Hay calls it: "Grimms' Law of Payment in Full". Part of her poem "The Bencfactors" illustrates this: 
... Be very sure/ Whenever you bargain for your heart's desire,/That whether in sober fact or fairy tale/ Grimms' Law of Payment in Full will still prevail./ If not today, then certainly tomorrow,/ As many a man discovers, to his sorrow. (Mieder, Disenchantments 2)

The "Grimms' Law," this "payment in full" for evil, is the essence of the punishment found in their tales. There is no room for ambiguity. Spörk mentions in her Studien zu ausgewählten Märchen der Brüder Grimm how in the Märchen "Aschenputtel" the severe punishment of the stepsisters getting their eyes pecked out by doves is classic Grimm : "Die Bestrafung der Stiefschwestern am Schluß des Märchens ist Einfügur--und in ihrer Grausamkeit ein bezeichnendes Merkmal des Grimmschen Märchenstils" (128).

Whether Grimm fairy tales are more gruesome than versions from other countries is a question open for debate, but people often view them that way. Tatar, in her book The Hard Facts of the Grimms' Fairy Tales, mentions how Grimm stories have come "under heavy fire from educators, for the tales are generally held to be more gruesome and horrific than most other such stories" (185). Indeed, Jacob and Wilhelm added gruesomeness to the ending in "Aschenputtel," as one can see by examining the 1812 edition with the 1819 edition. The stepsisters, who said unkind things to Aschenputtel and teased her mercilessly, were punished with blindness in the $1819 K H M$ edition. In the 1812 version of the tale, 
the only punishment of the stepsisters was that they turned "pale" while watching the heroine's "good fortune." The punishment of the stepsisters in the edition of 1819 was a deliberate addition by the Grimm brothers as they chose to follow another version of the story different than the one they collected in 1812. But it was an intentional change; they could have stuck with the milder 1812 version when rewriting for the 1819 edition.

But do the Grimm brothers stand alone in presenting violent punishments in their fairy tales? This is a question that one can debate. Many say that other versions have as much gruesomeness as the fairy tales of the Grimm brothers:

The Grimms clearly had no monopoly on violence in fairy tales and folktales. The horrors of the stories, to borrow a phrase from Poe, are not really of Germany, but of the soul . . . . Violence and cruelty number among the hard facts of all fairy tales. The victimization/retaliation pattern that appears in one tale type after another invites the depiction of heartless behavior and merciless punishments. (Hard Facts 186-190)

Yet even if the Grimm brothers did stand alone in their depiction of specific consequences for evil deeds, the questions remain: Is telling children details of gruesome punishment a wise decision? Could it be good for their development? Do children expect punishment at the end of a tale? Does punishment add a 
sense of finality, justice and balance to a story? Many people have answered the cuestions affirmatively. The simple reason behind their opinion is that punishment is central to fairy tales.

Some people think that children by their very nature are fair and to them justice is rewarding the good and punishing the evil. They expect justice from their authorities. J.R.R. Tolkien in his essay on fairy tales mentions how:

Chesterton once remarked that the children in whose company he saw Maeterlinck's Blue Bird were dissatisfied 'because it did not end with a Day of Judgement . . . For children,' he says, 'are innocent and love justice; while most of us are wicked and naturally prefer mercy. (119)

The love for justice leads to children being "disappointed" when a villain gets off too easy (Tatar, Off with their Heads 31). Giambattista Basile, the seventeenth century author of the "Pentamerone" (a collection of fairy tales for children), remarks on how the ending to his version of "Cinderella" is too mild. The stepsisters in his version, entitled "The Cat Cinderella," "eilen voll Ärger Heim" (trans. in Bolte and Polivka 4:198), with the only punishment being their obvious jealousy. Basile realizes:

that this punishment seemed too mild to many people: 'There was no punishment that their haughtiness did not deserve and no penalty befitting their envy."' ( Lüthi, Once Upon a Time 63) 
Indeed. Basile says that the audience feels "cheated," because the punishment of the stepsisters in his "Cat Cinderella' is "too light" (Tatar, Off with their Heads 31 ). The entire nature of fairy tales calls for punishment that is beyond "too light. " Extremes are characteristic, as are contrasts, which Max Lüthi points out in his book on the style of fairy tales:

The polarities come into being in and of themselves, according to the law of opposite word meaning. Whoever says beautiful says or thinks ugly as well; reward calls forth its opposite, punishment. It follows . . . in accord with the overall style of the fairytales, something with which he is familiar, should push the poles far apart: not simply reward and punishment, but the highest reward and terrible punishment. (Fairytale as Art Form 95)

The "terrible punishment" that Lüthi mentions is what makes the fairy tale have finality. The standard ending, " $A$ nd they lived happily ever after," can only happen if the evil that interrupts happiness is eliminated. The closure that punishment brings to the fairy tale balances the story, which ties in to the characteristic of contrasts and extremes. The hero starts out at the beginning of the tale often in a helpless situation--but then ends in glory. As Tatar points out:

The fairy tale's movement from victimization to retaliation possesses a classic balance and symmetry. In the end, old scores are settled and wrongs are 
redressed. The sufferings inflicted on the victim or intended for him are ultimately visited on the adversary. (Hard Facts 182-183)

One could summarize justice in this way: giving the evil person the punishment he deserves. Isaac Bashevis Singer notes how important a positive outcome is, especially in literature for children. Self understood in his idea of a happy ending is the concept of justice, as he explains:

I try to give a happy ending to a story for a child because I know how sensitive a child is. If you tell a child that a murderer or a thief was never punished and never caught, the child feels that there is no justice in the world altogether. And I don't like children to come to this conclusion, at least not too soon. (12.13)

Children want to know that a villain is punished for his actions. Dégh, in her article on the place of Grimms' tales in the household, remarks how:

the just outcome of the struggle between recognized good and evil powers was what mattered, regardless of the frightening, cruel, gory detail or other potentially harmful elements. (93)

Lüthi justifies the extreme punishments in fairy tales, remarking that without them there is something lost, maybe the very thing that defines a fairy tale in the first place: "If severe and unmistakable punishment were to be completely eliminated from the fairytale . . . 
it would be a stylistic and esthetic loss" (Fairytale as Art Form 153). The esthetic characteristic of punishment is embodied in extremes:

Beautiful and ugly, good and bad, success and failure, helplessness/perplexity and successful outcome, emergency and rescue, enchantment and disenchantment, reward and punishment, gold and pitch, death and resuscitation, appearance and reality . . real and unreal--these and other polarities run through the world of the fairytales in manifold variations. (Lüthi, Fairy Tale as Art Form 95)

Grimm fairy tales have been translated into English since Edgar Taylor's German Popular Stories (1823-1826). Yet not until the 1936 American translation by Wanda Gag, entitled Tales from Grimm, was there an "escape" from "nineteenth-century diction" (Adderson 73). However, it was probably Walt Disney, via the motion picture industry, who truly popularized Grimm in this country. Dégh notes how:

Some of the Grimm tales achieved great popularity through animated film and later television productions. Walt Disney's 'Snow White and the Seven Dwarves,' in particular, made film history in 1938 with an overnight world success. It also marked the beginning of a new era for tale communication through media. (101)

The pictures that Walt Disney illustrated for his versions of classic fairy tales imprinted an image of how a fairy tale figure 
looks. German critics of these images have said they are a disgrace to the genre of the fairy tale. D. Udo de Haes remarks in his book Kinderwelt Märchenwelt on the different types of "lustigen" illustrations:

Walt-Disney-Zwerge . . vorgestellt als drollige Komiker mit roten Trinkernasen . . . zum Glück lassen sich nicht alle Märchen-lllustratoren auf diese Schändung ein. Es gibt auch solche, die die Märchen noch ernst nehmen.

Maurice Sendak, author of various books for children, including Where the Wild Things Live, remembers the criticism in his New York school toward the Disney versions of classics: "In school, I leamed to despise Walt Disney. I was told that he corrupted the fairy tale and that he was the personification of poor taste" (108). Sendak now has a great deal of respect for Disney, but it took him many years to change the initial negative stereotyping of Walt Disney's rendition of some fairy tales.

Disney has not only been criticized for "corrupting" classic fairy tales, but also for the occurrence of certain types of violence in his films. Americans are quick to complain about the intense Disney films that have been created in the name of entertainment, widely used for children. However, similar to the Grimm brothers, Walt Disney did not consider his films for children, per se. He said: "I do not make films primarily for children. I make them for the child in all of us, whether we be six or sixty" (Behlmer 60). But as the Grimm 
stories are a standard for the fairy tale genre, so Disney is a household word for motion pictures for children.

Disney's first full length motion picture, "Snow White and the Seven Dwarfs," was released in 1937 and won a special Academy Award in 1939. Despite its overall success, it was also criticized for being frightening for children. After the film first came out, some children "had to be carried from the theater screaming at even the fairly mild, often gently charming version of Snow White that Disney finally made" (Schickel 207). The wicked stepmother is generally blamed for the fearsome reaction in children. Other Disney films over the years have been criticized for their intensity as well.

When it comes to fairy tales for children, definite debate exists on the issue of what version is considered more appropriate. In the above comic of the boy and his mother reading fairy tales, his comment, "Witches poisoning princesses, giants falling off beanstalks, wolves terrorizing pigs . . . and you complain about violence on TV," tells something of the true nature of fairy tales.

But in comparing Grimm fairy tales with other versions, what significance can one see in their differences? Is there a cultural reason that Disney and Golden Books adapted the stories into the versions they give to the $A$ merican public used for children? Tatar quotes historian Robert Darnton, who says yes: "Folktales are historical documents . . . each colored by the mental life and culture of its epoch" (qtd. in Preface Hard Facts XiX). 
This Grimm style of extremes and contrasts is seen in specific fairy tale examples. In the Märchen "Sneewittchen," "Aschenputtel," and "Rotkäppchen," punishment of the evil forces is consistent with the form of fairy tales: in extremes.

Interestingly, in both "Sneewittchen" and "Aschenputtel," and other Grimm stories, the wicked mother figure is not the biological mother but the stepmother. Sometimes there was a deliberate change made from one edition to the next. For example in "Sneewittchen," the biological mother in the 1812 edition is the jealous queen with the maggic mirror while in the 1819 edition the mother dies and is replaced with the stepmother.

In the Grimm story the relationship seems to be fine between stepmother and daughter until Sneewittchen turns seven years, when the plot thickens: "Sneewittchen aber wuchs heran und wurde immer schöner, und als es sieben Jahr alt war, war es so schön wie der klare Tag und schöner als die Königen selbst. Als diese einmal ihren Spiegel fragte:

'Spieglein, Spieglein an der Wand,

Wer ist die Schönste im ganzen Land?'

so antwortete er:

'Frau Königen, Ihr seid die Schönste hier;

Aber Sneewittchen ist tausendmal schöner als lhr.'

( 1819 KHM 194)

Jealousy overtakes the stepmother at the thought that she is no longer the most beautiful in the land. She orders a huntsman to 
kill the seven year old Sneewittchen and bring back her lungs and liver as proof. The servant has mercy on the child and lets her run away; he kills a young boar instead, and brings back its lungs and liver. The stepmother then boils the lungs and liver of the boar in salt water and eats them, thinking she is eating parts of Sneewittchen. This is a mild case of cannibalism, a distinctive yet not exclusive quality of tales by the Grimm brothers.

The Bechstein version of "Sneewittchen," entitled "Schneeweißchen," has a similar account of lungs and liver being eaten by the stepmother, who "verzehrte es und war froh, daß sie, wie sie vermeinte, nun wieder allein die Schönste sei im ganzen Land" (240).

The Disney version of the tale, "Walt Disney's Masterpiece: Snow White and the Seven Dwarfs," which acknowledges the source of the story being the Grimm brothers, digresses from Grimm in several areas, beginning with the assumed cannibalism. Although the Disney stepmother orders the huntsman to kill Snow White and bring back her heart, the stepmother does not eat the organ (which is actually that of a wild animal as in Grimm). The cannibalistic section of the Grimm version may have been socially unacceptable for American palates. Disney in essence set a Standard as to what United States audiences would tolerate. This could be considered a cultural difference in the adapted version. Or maybe it is simply marketing. 
Also, Snow White is not seven years old as in the Grimm and Bechstein versions. One would guess by seeing Snow White in the Disney movie that she is at least fourteen years old.

The other distinctively violent section in the Grimm version of "Sneewittchen" is the punishment of the stepmother, where Grimm stands alone compared with Bechstein and Disney. At the wedding of Sneewittchen and the prince, the stepmother comes to see how beautiful the bride is. The last part of the tale tells what her punishment was for her meanness to the kind sneewittchen:

Aber es waren schon eiserne Pantoffeln über Kohlenfeuer gestellt und wurden mit Zangen hereingetragen und vor sie hingestellt. Da mußte sie in die rotglühenden Schuhe treten und so lange tanzen, bis sie tot zur Erde fiel. (1819 KHM 203)

It is clear in the version by Grimms that the punishment of dancing to death in red hot shoes is deliberate; that is, there is no accidental death of the villain, which the Grimm brothers are proud of. They explain in the 1812 Vorrede the representative extremes in their tales: "ebenso furchtbar die Strafe . . in glühenden Eisenschuhen mul3 es sich zu Tod tanzen" (Qtd. in Schmitt 139). The ending of the story gives the child the feeling that the evil stepmother got what she deserves, however extreme the punishment may be. 
In the Bechstein Märchenbuch, the ending is different and the punishment more abstract. Here the stepmother also went to the wedding of Schneeweißchen:

Und als sie in den Saal kam, trat ihr Schneewißchen als die allerschönste Königsbraut entgegen, die es jemals gegeben hatte, und da möchte sie vor Schrecken in die Erde sinken. Schneeweißchen aber war nicht allein die Allerschönste, sondern sie hatte auch ein großes edles llerz, das die Untaten, die die falsche Frau an ihr verübt hatte, nicht selbst rächte. Es kam aber ein giftiger Wurm, der fraß der bösen Königen das Herz ab, und dieser Wurm war der Neid. (248) Even though the Disney version of "Snow White" is said to follow Grimm, his ending is different. Disney tells it like this: after the dwarfs discover Snow White has been poisoned by the queen (who is the mean stepmother turned wicked witch), they chase her to the edge of a cliff in dark and stormy weather. She loses her balance and presumalbly falls to her death. Nthough there is a feeling of relief that she is gone, one does not sce her die. Her death is accidental and the deliberateness is missing. The difference in the types of deaths is significant. Dancing to death in red hot shoes is a painful and extreme picture of dying. While the Disney version, where the stepmother falls off a cliff, brings an assured end to life, the punishment is less extreme than in the Grimm version. 
Comparing another Grimm fairy tale, "Aschenputtel," with Bechstein's "Aschenbrödel," and Disney's "Cinderella," illustrates other distinct Grimmian qualities. In the Grimm version of "Aschenputtel" the stepsisters cut off their heal while they are trying on the lost shoe for the servant of the prince. Their mother encouraged them in this act of self-mutilation, ordering: "Hau die Zeh ab; wann du Königin bist, so brauchst du nicht mehr zu Fuß zu gehen" ( 1819 KHM 96).

The account by Bechstein is simpler and less violent: "Vergebens probierten die beiden Schwestern den kleinen Schuh; es war, als ob ihre Füße ordentlich größer würden" (265).

In the version by Walt Disney, which actually follows the rendition by Charles Perrault, the stepsisters do not cut off their heals to fit the shoe as with Grimm; instead they squeeze with all their might until the shoe bursts off the foot. Disney thereby adds a touch of humor instead of blood.

When it comes to punishment of the stepsisters for their evilmindedness towards Aschenputtel, many Americans are surprised at the severity. In the Grimmian account, the stepsisters felt compelled to go to the wedding:

Als die Hochzeit mit dem Königsohn sollte gehalten werden, kamen die falschen Schwestern, wollten sich einschmeicheln und teil an seinem Glück nehmen . . . da pickten die Tauben einer jeden das eine Auge aus. 
Hernach . . . da pickten die Tauben einer jeden das andere Auge aus. (1819 KHM 98)

The pecking out of the eyes of the stepsisters is a definite punishment for their evil deeds, as the Grimm brothers point out at the end of the story: "Und waren sie also für ihre Bosheit und Falschheit auf ihr Lebtag gestraft" (1819 KHM 98).

Bechstein has a similar account of consequences for the actions of the stepsisters, ending with the explanation: "und so waren sie für ihren Neid und ihre Bösheit mit Blindheit geschlagen ihr Leben lang" (265).

The ending in the seventeenth century Perrault rendition follows the opposite extreme of Bechstein and Grimm. The story mentions the wedding of Cinderella to the prince and then:

Cinderella was as good as she was beautiful. She set aside apartments in the palace for her two sisters, and married them the very same day to two gentlemen of high rank about the court. (68)

It has been suggested that the purpose of the perrault ending was to appease members of the aristocratic class which were his audience (Tatar, Ilard Facts 189). The idea of having an author try to please his audience is nothing new.

In the Disney version of "Cinderella" the stepsisters are equally wicked to the heroine. They tease her, tear her dress apart, and ridicule her. But in the end there seems to be no punishment or resolution. The story ends with the stepsisters watching with 
unbelieving and jealous eyes as Cinderella puts the perfect-fitting shoe on her foot. In the Perrault version of the story the stepsisters are verbally forgiven by Cinderella: in the Grimmian story they are specifically punished with blindness. In the Disney story, jealousy seems to be the only outcome of the stepsisters cruelty. Nlthough Disney credits Perrault for his adaptation, he leaves out the verbal forgiveness, following a middle ground between Grimm and Perrault. As in Basile's "Cat Cinderella," there is no punishment in the Disney version. Without punishment or some kind of a resolution to the story there seems to be no balance.

Although Disney left out the acts of perceived cannibalism, dancing to death in red-hot shoes, cutting off parts of the feet, and having one's cyes pecked out in the aforementioned stories, the American producer of entertainment for children is no stranger to critics for other elements of violence in his works. From his first fulllength motion picture, "Snow White and the Seven Dwarfs," in the 1930s, to "Lion King" in the 1990s, parents and critics have anatyzed the frightening scenes in films produced by Walt Disney Studios. The main question that comes to mind is the effect of violence on the child. Disney has chosen to exclude certain gruesome acts while allowing others to remain. This could be considered cultural, or marketing what is perceived to sell to the widest range of audience. Of course, Grimm and Perrault considered their audiences as well. 
A classic fairy tale involving the famous wolf is "Rotkäppchen," where the sick Grandmother and the innocent Red Cap are eaten by the wolf in the Grimm version of the tale. The picture of naivety is evident for adults. Rotkäppchen and the wolf in Grandmother's clothes have their well-known dialogue, where one can almost feel the growing tension of what is about to happen to Rotkäppchen.

"Ei, Großmutter, was hast du für große Ohren!"-. "Daß ich dich besser hören kann."

"Ei. Großmutter, was hast du für große Augen!"-"Daß ich dich besser sehen kann."

"Ei, Großmutter, was hast du für große Hände!".. "Dal3 ich dich besser packen kann."

"Aber, Grol3mutter, was hast du für ein entsetzlich großes Maul!"-.

"Daß ich dich besser fressen kann."

Kaum hatte der Wolf das gesagt, so tat er einen Satz aus dem l3ette und verschlang das arme Rotkäppchen (1819 KHM 108). Some people argue that this episode is too gruesome for certain children. And when it comes to the punishment of the wolf in the end for his voracious appetite, the Grimm version again has been criticized for its violence. In it, a hunter, who happens to come by the Grandmother's house, finds the wolf asleep and gets out a pair of scissors to cut open his stomach, in hopes of finding the missing woman. He rescues both the Grandmother and 
Rotkäppchen. After their escape, Rotkäppchen quickly fills the stomach of the sleeping wolf with rocks. When the wolf wakes up he, because of the heaviness of the rocks, collapses dead on the floor. The punishment for the human-eating wolf is clear. And by Grimmian standards justice was served. This is, as Sara Henderson Hay so poetically stated, Grimmian "Payment in Full" to the welldeserving wolf.

The Perrault version of the tale leaves something to be desired, maybe because the Grimm version is more popular. One seems to expect a happy ending. The Perrault version ends after the wolf eats up Little Red Riding Hood: "With these words the wicked Wolf leapt upon Little Red Riding Hood and gobbled her up" (76). The lack of justice leaves little closure to the story. As Lüthi suggested, esthetically there seems to be a loss (Fairytale as Art Form 153). The very nature of fairy tales calls for justice and closure.

The critics who have challenged the appropriateness of the gruesome acts in fairy tales have said that for a child to listen to a story about a wolf eating two human beings and then later being cruelly punished for it is too traumatic. The criticism has led to modern-day, less-violent twists on tales. Golden Book publishers have come up with their own version, where Grandmother:

hides out in a closet, frantically stitching together a ghost costume from linens. When the wolf pounces on Little Red, Granny-as-ghost bursts forth and frightens 
him away, and they all . . . . Well, some things never change. (Ingrassia 62-62)

The two main changes in the Golden Book adaptation--that the Grandmother and Little Red Riding Hood don't get eaten, and that the wolf does not die--make it a totally different story. The main elements of what make "Rotkäppchen" a story seem to be missing. Which leads to the questions: does the Golden Book adaptation take a concern for violence in literature for children too far? Is there cultural significance in the different versions? Or is it all a big marketing game with the main determining factor: what will sell and what will not in each individual country? Maybe it is a combination of the two as Maria Tatar seems to suggest:

The folkloric community operates as a kind of censor, endlessly revising the content of a tale until it meets with full approval. Thus it is not surprising to find radically different versions of the same tale as one moves from one cultural context to another. Each community or culture participates in its own unique oral narrative traditions, imbuing them with their particular mores and values. (Hard Facts 25) 


\section{CHAPTER III}

\section{CONCLUSION: GRIMM BROTHERS SET THE STANDARD}

The question of where fairy tales fit into the life of the child has been asked since the first publication of the Kinder-und Hausmärchen by the Grimm brothers. People have taken a wide variety of stances, mostly falling into four differing viewpoints. The first group believes one should read them as they are, with no expurgating, as for example P.L. Travers has asserted. Others think Grimm fairy tales are too extreme and prefer not to read them at all, as a modem day story teller interviewed by Kay Stone has vowed. A third group believes one should make careful, age-appropriate selections in their use. $\Lambda$ fourth group falls into the category of seeing the need to alter them, creating manifold adaptations. Disney and Golden Books have changed certain fairy tales to fit an image of what they deem appropriate for various audiences in the United States. For example, Disncy changed "Snow White" to leave out cannabalism and tortorous punishment; and Golden Books changed the story "Little Red Riding Hood" by leaving out the wolf-eating. human sections.

Because the Grimms created the genre of the fairy tale they define it in many ways. One of the aesthetic norms within their fairy tales is a world of order where evil is conquered and good is rewarded. Max Lüthi has summarized that the style of fairy tales embody cxtremes, including what the Grimm brothers are known for, extremes in punishment: "In accord with the overall style of the 
fairytales . . not simply reward and punishment, but the highest reward and terrible punishment" (Fairytale as Art Form 95). The Grimm brothers never apologized for the graphic punishments in their stories; instead they defended them in their entirety.

Lüthi further seems to suggest that altering fairy tales by removing some of the extreme qualities causes an esthetic loss to the genre. Thereby, he justifies Grimm and suggests one take them as they are: "If severe and unmistakable punishment were to be completely eliminated from the fairytale . . it would be a stylistic and esthetic loss" (Fairytale as Art Form 153). The Grimm brothers felt that nature itself defends their collection and that those who criticize their work cannot demand that it be altered:

Nichts besser kann uns verteidigen als die Natur selber, welche diese Blumen und Blätter in solcher Farbe und Gestalt hat wachsen lassen; wem sie nicht zuträglich sind nach besonderen Bedürfnissen, der kann nicht fordern, daß sie deshalb anders gefärbt und geschnitten werden sollen. (Vorrede 1819 KHM 31 )

Because the Grimms felt their fairy tales came from the Volk. they emphasized that the source of their stories was nature. At the time of the first publication of the $K H M$ in 1812 there was a lack of good literature for children. The Grimm brothers allude to this in their $1812 K H M$ preface, commenting on how the literature that was available was disallowed for children: "doch immer den Kindern das Ihrige aus den Händen rissen und ihnen nichts dafür gaben" (qIt. in 
Schmitt 143). And when there was literature for children, the quality of it was questionable to the Grimm brothers. They felt the unnatural lessons that were added on at the end of a story made for literature that was lacking in substance: "Selbst wer an sie gedacht, konnte es doch nicht lassen, Manieren, welche die Zeitpoesie gab, hineinzumischen" (qrd. in Schmitt 143).

They made it clear that a natural approach to literature for children, where a lesson was not purposefully added but instead grew out of the story, was the most appropriate. As they explain in the 1812 preface, one will naturally learn about life from their tales: Aus diesen Märchen eine gute Lehre . . . erwächst daraus, wie eine gute Frucht aus einer gesunden Blüte ohne Zutun der Menschen. Darin bewährt sich jede echte Poesie, daß sie niemals ohne Beziehung auf das Leben sein kann, denn sie ist aus ihm aufgestiegen und kehrt zu ihm zunück, wie die Wolken zu ihrer Geburtsstätte, nachdem sie die Erde getränkt haben. (qtd. in Schmitt 139-140)

The idea that what is natural is something good for children seems to be the overall Romantic theme the Grimm brothers keep coming back to in defending the importance of their work in its entirety. They further state that one should strive after it: "Gedeihlich aber kann alles werden, was natürlich ist, und danach sollen wir trachten" (Vorrede $1819 K H M 31$ ). And the naturalness of their tales is reason enough to accept them as they are. 
Yet even as the Grimm brothers defend the entirety of their collection in the $K H M$ Vorrede, they also allow for a simpler approach. It might be the way a child views them-to simply enjoy them for what they are. The Grimm brothers Summarize Märchen: Wo sie noch da sind, leben sie so, daß man nicht daran denkt, ob sie gut oder schlecht sind, poetisch oder für gescheite Leute abgeschmackt: man weiß sie und liebt sie, weil man sie eben so empfangen hat, und freut sich daran, ohne einen Grund dafür . . . ihr bloßes Dasein reicht hin, sie zu schützen. (Vorrede $1819 K H M 30$ ) And that is the view one should have towards the Grimm brothers and their collection of fairy tales, to enjoy them and to protect them by taking them as they are. Kurt Stiasny seems to understand the essence of the Grimm brothers. He reiterates the universality of fairy tales and the ageless truths found in them:

Wir sehen, Märchen gelten nicht für ein bestimmtes Alter, auch nicht für ein bestimmtes Zeitalter, sie gelten immer, weil sie immergültige Wahrheiten, z.T. verschlüsselt, über Jahrhunderte und Jahrtausende getragen haben und getragen werden. (11)

Perhaps sceing fairy tales as Charles Dickens has would bring a fresh perspective. He saw the beauty in them and hailed them as important instruments for teaching about living:

It would be hard to estimate the amount of gentleness and mercy that has made its way among us through 
these slight channels. Forbearance, courtesy, consideration for the poor and aged, kind treatment of animals, the love of nature, abhorrence of tyranny and brute force--many such good things have been first nourished in the child's heart by this powerful aid. (qtd. in Tatar, Off with their Heads 17)

One needs to leave Grimm Märchen as they are. Because the Grimm brothers defined the genre, they set the aesthetic norm of what a fairy tale should be. Fairy tales present a world where good prevails and evil is punished; they tell a tale of justice and that the art of wishing is still alive. 


\section{Works Cited}

Alderson, Brian. "The Spoken and the Read: German Popular Storics and English Popular Diction." I laase 59.74.

Bechstein, Ludwig. Märchenbuch Köln: Atlas Verlag, 1940.

Behlmer, Rudy. Behind the Scenes. New York: Samuel French, 1990.

Bolte, Johannes und Georg Polivka. Anmerkungen zu den Kinderund Hausmärchen der Brüder Grimm. Band 1, 4 Hildesheim: Georg Olms Verlagsbuchhandlung, 1963.

Bottigheimer, Ruth B. Grimms' Bad Girls \& Bold Boys: The Moral \& Social Vision of the Tales. New Haven: Yale University Press, 1987.

Campbell, Joseph. "Folkloristic Commentary." The Complete

Grimm's Fairy Tales. New York: Pantheon books, 1972. 833862.

Dégh, Linda. "Grimm's Household Tales and Its Place in the Household: The Social Relevance of a Controversial Classic." Western Folklore 38 (1979): 83-103.

de Haes, D. Udo. Kinderwelt Märchenwelt Stuttgart: J. Ch. Mellinger Verlag, 1965.

Dollerup, Cay, et. al. "The Ontological Status, the Formative Elements, the "Filters" and Existences of Folktales." Eabula 25 
(1984): $241-265$.

Egoff, Sheila, G.T. Stubbs and L.F. Ashley, eds. Only Connect:

Readings on Children's Literature, Second edition. Toronto: Oxford University Press, 1980.

Ellwanger, Wolfram and Amold Grömminger. Märchen-Erziehungshilfe oder Gefahr?. Freiburg i.Br.: Verlag Herder, 1977.

Gerstner, Hermann. Brüder Grimm. Hamburg: Rowohlt Taschenbuch Verlag, 1994.

Goethe, Johann Wolfgang von. Goethe's Werke Band XII. Hamburger Ausgabe. München: CH Beck Verlag, 1973. 498. Grimm, Hermann. "Erinnenungen von Herman Grimm." KHM, 1819 edition. München: Winkler-Verlag, 1956. 5-27.

Grimm, Jacob und Wilhelm. Kinder-und Hausmärchen: Gesammelt durch die Brüder Girimm. 1819 Auflage. München: Bardtenschlager Verlag.

... Vorrede. Deutsche Sagen. München: Winkler Verlag. 7.24.

… Vorrede. KHM. 1819 ed. München: Winkler Verlag, 1956. 29-37.

Haase, Donald. Introduction. Haase 9-21.

..., ed. The Reception of Grimms' Fairy Tales: Responses. 
Reactions. Revisions. Detroit: Wayne State University Press, 1993.

Hay, Sara Henderson. "The Benefactors." Disenchantments: $\Delta n$ Anthology of Modem Fairy Tale Poetry. Wolfgang Mieder, ed. Hanover and London: University Press of New England, 1985.

Hetmann, Frederik. "Die mündlichen Quellen der Grimms oder die Rolle der Geschichtenerzähler in den Kinder-und Hausmärchen." The Germanic Review LXII. 2, (Spring 1987): 83-89.

Hornysansky, Michael. "The Truth of Fables." Egoff, Stubbs and Ashley 121:132.

Hyman, Trina Schart. "Cut It Down, and You Will Find Something at the Roots." Haase 293-300.

Ingrassia, Michele. "What if the Three Pigs tried Conflict Mediation?" Newsweek 123, 5. 31 Jan. 31, 1994: 62-63.

Lüthi, Max. The Fairytale as Art Form and Portrait of Man.

Bloomington: Indiana University Press, 1984.

$\cdots$ Once Upon a Time: On the Nature of Eairy Tales. New York:

Frederick Ungar Publishing Co.

McGlathery, James M., ed. The Brothers Grimm and Folktale.

Chicago: University of Illinois Press, 1988. 
Mieder, Wolfgang. Disenchantments: An Anthology of Modem Fairy Tale Poetry. I Ianover and London: University Press of New England, 1985.

... Tradition and Innovation in Folk Literature. University of Vermont: University Press of New England, 1987.

Neumann, Siegfried. "The Brothers Grimm as Collectors and Editors of German Folktales." Haase 24-35.

Nibelungenlied. Das. Nach der Ausgabe von Karl Bartsch. 22 ed. Mannheim: F.A. Brockhaus, 1988.

Perrault, Charles. Perrault's Complete Fairy Tales. New York: Dodd, Mead \& Company, Inc. 1961.

Pickard, P.M. LCould a Tale Unfold London: Tavistock Publications.

Rölleke, Heinz. Die Märchen der Brüder Grimm, 3. Auflage, Bonn: Bouvier Verlag, 1992.

… Wo das wünschen noch geholfen hat. Bonn: Bouvier-Verlag Herbert Grundmann, 1985.

Schickel, Richard. The Disney Version. New York: Simon and Schuster, 1968.

Schiller, Friedrich. Wallenstein: Die Piccolomini III, 4. Stuttgart: Reclam, 1988.

Schmitt, Hans-Jürgen, Herausgeber. Die Deutsche Literatur in Text 
und Darstellung: RomantikI. Vorrede 1812 KHM. Stuttgart: Reclam, 1980. 134-149.

Schneider, Wilfried. "Kinder-und Jugendliteratur in Film, Funk und Fernsehen." Kinder-und Jugendliteratur. München: WilhelmFink - verlag, 1979. 341-357.

Sendak, Maurice. "Walt Disney." Caldecott \& Co.: Notes on Books \& Pictures, New York: Farrar, Straus and Giroux, 1988. 107-117. Singer, Isaac Bashevis. "On Writing for Children." Children's Literature 6, 1977.

Spörk, Ingrid. Studien zu ausgewählten Märchen der Brüder Grimm. 2. Auflage. Königstein: Verlag Anton Hain Meisenheim GmbH, 1986.

Stiasny, Kurt. Was Grimmsche Märchen erzählen: Original und Deutung. Staffhausen: Novalis Verlag, 1994. Stone, Kay. "Once Upon a Time Today: Grimm Tales for Contemporary Performers." Haase 250-267. ... "Three Transformations of Snow White." McGlathery 52-63. Tatar, Maria. The Hard Facts of the Grimms' Fairy Tales. New Jersey: Princeton University Press, 1987.

-.. Off With Their Heads. Princeton: Princeton Universitty Press, 1992. 
... "Wilhelm Grimm/Maurice Sendak: Dear Mili and the Literary Culture of Childhood." Haase 207-227.

Tolkien, J.R.R. "Children and Fairy Stories."Egoff, Stubbs and Ashley $111-120$.

Travers, P.L. "Only Connect." Egoff, Stubbs and Ashley 183-206.

Yolen, Jane. "The Brothers Grimm and Sister Jane." Haase 283-288. 